\title{
International Retailing as Embedded Business Models
}

Steve Burt (Contact Author)

Professor of Retail Marketing

Institute for Retail Studies

Stirling Management School

University of Stirling

STIRLING, FK9 4LA, Scotland

email : s.1.burt@stir.ac.uk

Ulf Johansson

Professor

Department of Business Administration

Lund University, PO Box 7080

22007 LUND, Sweden

email: ulf.Johansson@fek.lu.se

John Dawson

Professor Emeritus

Universities of Edinburgh and Stirling, Scotland.

email: john.dawson@ed.ac.uk

Revised February 2015 


\title{
International Retailing as Embedded Business Models
}

\begin{abstract}
As retailers internationalise they interact with diverse socio-political-economic environments and the activities, processes, behaviours and outputs underpinning their business models evolve over time and space. Retailers are not passive, and through managerial agency they interpret the environment to compete and further their own commercial aims. Consequently, mutual interaction with the host environment means that changes may also occur in the established institutional norms in a market. Most existing studies have focused on the implications of territorial embeddedness for internationalising retailers. In this paper we also consider the societal and network forms of embeddedness identified by Hess, and illustrate how retailers transfer, negotiate and adapt their business model as they embed themselves in different institutional environments. A case study of IKEA is used to illustrate the synthesis of these two frameworks.
\end{abstract}

Key words: Embeddedness, Business Model, International Retailing, IKEA

JEL : D22, F6, F23, L81, M16 


\section{International Retailing as Embedded Business Models}

\section{Introduction}

Internationalisation is a core element of business strategy for many retailers. Retailers from a variety of sectors, governance forms and scales of operation are involved. There are particular challenges faced by retailers in internationalisation because of the physical location of networks and local operational relationships which exist at the interface of production and consumption.

Over the past four decades most academic studies of retail internationalisation (see for examples, Hollander, 1970; Goldman, 1981; Treadgold, 1990; Burt, 1991; Dawson, 1994, 2007; Helfferich et al., 1997; Gielens and Dekimpe, 2001; Rugman and Girod, 2003; Burt et al., 2008; Alexander and Doherty, 2010) have viewed implementation from a broad market perspective with the incoming retailer and the host environment taken as generic entities. More recent studies of what needs to be adapted, why adaptations might be considered and how they are achieved have more nuanced considerations that explore particular retailers and different institutional environments. There has also been recognition that rather than simply being passive responders to the host environment, retailers may themselves be agents of change in that market, using their business model to shape the market to the strategic and operational advantage of the retailer. Thus, Lowe and Wrigley's and Gamble's use of 'hybridisation' (Lowe and Wrigley, 2010; Gamble, 2010), Dicken's distinction of 'firming places' and 'placing firms' (Dicken, 2000; 2003) and the market driving concept (Tarnovskaya, 2007; Tarnovskaya et al., 2008) have generated discussion on the way retail firms change the market and also adapt to it in complex ways. The former binary distinction of market standardisation or adaptation is no longer appropriate.

We build on these emerging themes by considering the internal aspects of the retail business model, its components, dynamics and outputs, and those aspects of the host environment which may determine (or be determined by) the behaviours and activities of retail organisations. In doing so, we draw on the concept of embeddedness which has many different interpretations across a range of disciplines, for examples see Dacin et al., (1999) and Heidenreich $(2012 \mathrm{a} ; 2012 \mathrm{~b})$. The aim is to explicate how the concept of embeddedness can provide a better understanding of the process of retailer internationalisation and 
particularly, via consideration of the components of the retail business model, the operational implementation. By focusing on the internationalisation of IKEA, we seek to build on and extend the view of Hess (2004) that embeddedness as 'a concept has to be spatial-temporal, incorporating the formation and change of social structures in time and space.' (p181)

The structure of the paper is as follows. First we discuss embeddedness and its applications within retailing. Then we consider the business model concept and what this means in retailing. Thirdly, we synthesise the two concepts through a case study of IKEA. Finally we provide a conclusion, evaluation and pointers for the development of this research agenda.

\section{Embeddedness Within International Retailing}

That the retail activities of international retailers take different forms in different countries is unsurprising. Granovetter (1985) argued that the economy is an 'instituted process' based on a dynamic institutionalized social order. These social orders and institutions will clearly be country specific. According to the Granovetterian view,

'Embeddedness was first interpreted as the involvement of firms in social relations, the characteristics of which, through the embeddedness relations, became manifested in how firms organise and operate. Influences from the various social relations affect the way economic actors think and behave, often without their noticing it.' (Oinas, 1998: p198).

The Granovetter perspective has become accepted as the basis for many studies, for example Tzeng and Uzzi (2000); and Heidenreich (2012a; 2012b). Accepting this view implies that the societies in which an international retailer operates influence the operating systems and processes of that retailer within each local market economy.

However, the fundamental role played by retailing in society generates both a response to and a shaping of the social order. Retail firms exert pressures to make changes to the social order, which are beneficial to the retailer's objectives. The result is the different outcomes of activity of a retailer in the different economies in which it is present over time and space, in the latter case at several scales (Wood et al., 2014). Every retailer is deeply embedded in its home society and has to become similarly embedded in the host market when it internationalises. Although embedded in social order, retailing is, almost exclusively, a forprofit element in an economy. In competing, managerial agency is used to undertake purposeful actions to respond to and to change not only the social order but also economic 
relationships. In both re-active and pro-active ways the retailer is deeply embedded in the local market in which it operates and thus variants of its underlying business model are evident in these different markets.

Granovetter (1992) makes a distinction between relational embeddedness, based on dyadic relationships, and structural embeddedness, based on a social network with multiconnectivity of relationships (Moran, 2005). Both are relevant in international retailing with the network of relationships in structural embeddedness being particularly important and complex. Zukin and Di Maggio (1990) distinguish cognitive, cultural, structural and political embeddedness. In each type a different mix of institutions is involved, and in the context of international retailing the different types will have different relative roles in the markets involved. Halinen and Törnroos (1998) suggest six types of embeddedness: temporal, spatial, social, political, market and technological, which are argued as relevant to business networks irrespective of sector of economic activity. All of these studies, whilst considering the types and dimensions of embeddedness, are of a generic and conceptual nature, as Fletcher and Barrett (2001), point out, 'Although there have been a number of conceptual studies in the area of embeddedness and business networks, empirical research in the area of embeddedness of networks in an international context is sparse' (p563). They use a case study to focus on the mechanisms and dimensions of embeddedness within a business network paradigm and identify the presence of embeddedness within social, technological, regional, infrastructural, institutional, and market networks. The conclusion to be drawn from these studies is that embeddedness takes place in multiple networks that link the firm into its supportive social order. In different social orders and market economies the network structures will differ and the processes of embeddedness will reflect these differences.

Building on these earlier studies Hess (2004) argues the need for clearer definitions and extends the idea of spatial embeddedness beyond its general interpretation as passive territorial embeddedness in business networks. A focus on the complexity of the spatial element of embeddedness relates the concept directly to international retailing. Hess identifies three 'fundamental categories of embeddedness' (p178) as: societal embeddedness, network embeddedness and territorial embeddedness. All three are relevant to the study of international retailing.

Societal embeddedness relates to the history and societal foundations of the organisation involved. Hess likens this to a 'genetic code' of the organisation. 'Societal embeddedness 
also reflects the business systems idea of an institutional and regulatory framework that affects and in part determinates an actor's behaviour.' (Hess, 2004: p177). The institutional framework in which the firm operates creates a set of values and norms that influence the vision and culture of the firm. This framework however is not deterministic. For Hess societal embeddedness is generated both by the external environment and by internal agency of the organisation. In the context of retailer internationalisation, societal embeddedness can be construed as the 'genetic code' of the retailer as developed in its home market, with this code being transferred to a new market society as the organisation extends its sphere of operations. Transference, rather than adaption, is a dominant process in societal embeddedness as the organisation expands. An important feature of societal embeddedness is the constant evolution in the home operations of the organisation, with these evolutionary traits transferred to a foreign operation. The 'genetic code' is modified as new instituted markets are added and also as influential actors, for example the CEO, change internal agency relationships. In international retailing, societal embeddedness involves a process of transfer of the culture and values of the firm.

Network embeddedness relates to the 'structure of relationships among a set of individuals and organizations regardless of their country of origin or local anchoring in particular places.' (Hess, 2004: p177). 'Network' has to be considered in its non-spatial meaning. Network embeddedness involves inter-organisational and inter-personal relations, both formal and informal. Negotiation is a dominant process in network embeddedness. It encompasses the negotiated value chain of the retailer including its network of customers and suppliers, in addition to the various networks linking the firm into the commercial culture of the market. For retailing some networks are bounded by the country of retail operations, some are inter-country networks, whilst other networks are non-spatial in form. As the network expands and contracts and as members of the network use knowledge to re-negotiate relationships and their positions, power roles change and network embeddedness evolves. Moves by a retailer into new markets will affect the dynamics of intra-network relationships and change many aspects of network embeddedness. Many of the studies in the industrial networks literature (Håkansson and Ford, 2002; Håkansson et al., 2009), consider network embeddedness implicitly but do not place it in a wider embeddedness context. These studies of networks rarely consider societal embeddedness and territorial embeddedness.

Territorial embeddedness relates 'to the extent to which an actor is 'anchored' in particular territories or places' (Hess, 2004: p177). This aspect of embeddedness is not totally distinct 
from societal embeddedness as the social order underpinning societal embeddedness has a territorial context but the emphasis in territorial embeddedness is on adaption processes rather than transfer activities. Distinguishing territorial embeddedness from societal embeddedness is useful in the context of retailer internationalisation as it emphasises the adaptions that an international retailer has to make in response to local institutional structures in each of its markets. Different geographical markets require different adaptive responses and actions by the retailer. For the retailer all territorial markets are different and each requires some degree of adaption. The distinction between territorial embeddedness and societal embeddedness is further illustrated by Taconelli and Wrigley's (2009) dissection of territorial embeddedness into adaptions to consumer markets and consuming cultures, logistics and supply networks (although here there is interaction with network embeddedness), and real estate markets and regulations on rights of establishment. Territorial embeddedness therefore has a definite spatial dimension with the scale of geography also being relevant as indicated by Wood et al, (2014).

Underpinning the typology proposed by Hess is an implicit perception that embeddedness is more a response by the firm to its social-economic-political environment rather than a shaping of that environment by the firm. Using Hess's approach in the context of international retailing requires consideration of the very active role that many retailers have in shaping the socio-commercial order. The processes of transfer, negotiation and adaption within the three categories of embeddedness therefore involve the dialectics of mutual interaction of the retail firm with society, network and territory.

By far the majority of empirical studies on embeddedness focus on firms in the production sectors; few explore services and even fewer explicitly explore retailer embeddedness. Important exceptions are the studies of Wrigley and Coe together with their colleagues. This relative lack of interest in using embeddedness as a framework for understanding the activity of retailers is surprising since retailers whether operating a single outlet or a chain of 10,000 outlets are, as agued above, intimately embedded in a social order and a market economy comprising a social, economic, spatial and temporal ordering of institutions. Whilst even in a domestic situation there are spatially related institutional differences in operating stores in, say, Leeds compared with London, or Milan compared with Palermo, a consideration of embeddedness is particularly useful in the case of international retailers. In such cases managing the contrasts between the social order of home and, often multiple, host social orders becomes critical to firm performance. 
In several related studies Wrigley et al., (2005), Coe and Lee (2006; 2013), Lowe and Wrigley (2010), and Wood et al., (2014) have used the Hess framework, and particularly territorial embeddedness, to explore the localisation practices of Tesco in South Korea and the USA. Coe and Lee (2013) showed the 'deepening' of Samsung-Tesco's territorial embeddedness in South Korea pertaining to format innovation, the development of supply networks and the broadening base of retail and cultural services offered' (p330). These studies, and others that imply territorial embeddedness by using the term 'glocalisation' (for example Matusitz and Forrester, 2009; Matusitz and Leanza, 2009; Matusitz and Reyers, 2010; Dupuis and Fournioux, 2006; Chinomona and Sibanda, 2012), show the potential value of the concept of embeddedness but they also point to the need to interpret it in ways relevant to retailing. For example, Wrigley et al., (2005) argue that retailers exhibit 'an unusually high level of investment in embeddedness in host markets, and it is this high degree of embeddedness which, in our view, is critical in distinguishing the retail TNC from its manufacturing counterparts' ( $\mathrm{p} 440$ ). In making the concept relevant to retailing it is also important to see embeddedness operating at different scales in the market. Wood et al., (2014) point to this multi-scalar aspect of the concept in their study of Tesco in Asia. Markets in retailing have an important local context, particularly for the consumer, alongside regional and national dimensions that impinge on the managerial processes in internationalisation. Whilst accepting the importance of territorial embeddedness, nonetheless, it is important to consider how Hess's other types of embeddedness are also relevant to retailing.

For the international retailer the activities associated with the three types of embeddedness can be seen to operate in different ways for different retail sectors. There are differences in the process of embeddedness for organisations involved in, for example, food and grocery retailing from those in the retailing of fashion apparel or electronics. Strategic and operational practices differ by sector of retailing, reflectinglor reflected in the underlying business model. For example, the balance between retailer branding and manufacturer branding within the product range is different. In electronics and toys, manufacturer branding has remained very strong so manufacturer networks are important to a retailer in becoming embedded in a market. In fashion apparel the retailer has greater control over the brand and how the brand is presented in the market (Moore et al., 2000; Burt and Mavrommatis, 2006), so the retailer rather than the supplier has control over network embeddedness with the retail brand also being an essential part of societal embeddedness. The food and grocery sector is in an intermediate position with a balance sought between retailer brand control and the retailer 
acting as an 'agent' for manufacturer brands (Kumar and Steenkamp, 2007). In this case territorial embeddedness is important in building a local brand range offer for local consumers. Branding is one example of sectoral differences, there are others associated with different aspects of the respective sectors as illustrated in Figure 1.

Figure 1: Examples of embeddedness in alternative retail sectors in international retailing

\begin{tabular}{|c|c|c|c|}
\hline \multirow[b]{2}{*}{ Retail Sector } & \multicolumn{3}{|c|}{ Categories of Embeddedness } \\
\hline & Societal & Network & Territorial \\
\hline $\begin{array}{l}\text { Food and } \\
\text { Grocery }\end{array}$ & $\begin{array}{l}\text { Transfer of established } \\
\text { practices and methods } \\
\text { for buying and sourcing } \\
\text { Transfer of system } \\
\text { technologies for } \\
\text { administration }\end{array}$ & $\begin{array}{l}\text { Negotiation with } \\
\text { suppliers for effective } \\
\text { supply chain } \\
\text { management } \\
\text { Negotiation with } \\
\text { governmental } \\
\text { agencies on } \\
\text { competition, rights to } \\
\text { establishment and } \\
\text { consumer policies }\end{array}$ & $\begin{array}{l}\text { Adaption of product } \\
\text { ranges and } \\
\text { merchandising to } \\
\text { respond to local taste } \\
\text { and diets } \\
\text { Sales format adaptions } \\
\text { for local market } \\
\text { regulations } \\
\text { Finessing } \\
\text { communication } \\
\text { messages as part of local } \\
\text { adaptions }\end{array}$ \\
\hline $\begin{array}{l}\text { Fashion } \\
\text { Apparel }\end{array}$ & $\begin{array}{l}\text { Transfer of corporate } \\
\text { and product brands } \\
\text { developed in home } \\
\text { market. } \\
\text { Transfer of fashion } \\
\text { 'look' and design } \\
\text { principles }\end{array}$ & $\begin{array}{l}\text { Development of } \\
\text { fashion hubs as } \\
\text { sourcing and } \\
\text { distribution centres. } \\
\text { Negotiation of clusters } \\
\text { of store locations in } \\
\text { key shopping centres }\end{array}$ & $\begin{array}{l}\text { Product adjustments of } \\
\text { style, colour, ranges, } \\
\text { sizing etc. for local } \\
\text { markets } \\
\text { Adaption of service } \\
\text { activity and customer- } \\
\text { employee interaction }\end{array}$ \\
\hline $\begin{array}{l}\text { Electronics } \\
\text { and } \\
\text { Entertainment }\end{array}$ & $\begin{array}{l}\text { Transfer of } \\
\text { management control } \\
\text { systems } \\
\text { Transfer of global } \\
\text { perspective on sourcing }\end{array}$ & $\begin{array}{l}\text { Negotiation to use the } \\
\text { product brand } \\
\text { relationships of major } \\
\text { manufacturers } \\
\text { Negotiated use of } \\
\text { supplier logistics } \\
\text { networks }\end{array}$ & $\begin{array}{l}\text { Adaption of } \\
\text { merchandising and sales } \\
\text { practices to local } \\
\text { markets } \\
\text { Service rather than } \\
\text { product adjustments to } \\
\text { create embeddedness }\end{array}$ \\
\hline
\end{tabular}

The concept of embeddedness can therefore be used to develop a framework for gaining a better understanding of the activity of retailers when they enter and subsequently develop in a foreign market. Embeddedness is not only a process of managerial agency of the retailer in this situation but also a state of mutual interaction between the retailer and the social order in 
which the market operates including the networks of which the retailer is a member. This two way process generating embeddedness is very evident when considering retailers international activities but it has had limited consideration to date. Exploration of the reflective process involves consideration of the ways that a retailer changes the social order and market as they become increasingly embedded. To explore this process requires an understanding of the business model of the retailer.

\section{Business Models in Retailing}

The second strand in our consideration of international retailing is the business model used by the retailer for its international activities. The business model provides:

"the blueprint of how a company does business. It is the translation of strategic issues, such as strategic positioning and strategic goals into a conceptual model that explicitly states how the business functions" (Osterwalder et al., 2005: p 4).

The business model links strategy to implementation and is the basis of competitive advantage. As such the business model exploits different forms of embeddedness in generating a competitive offer to consumers. Several retailers within a sector may seek to satisfy the same broad customer needs through similar product and service strategies, but they will do so through different business models and apply these models using different interpretations of the forms of embeddedness. By framing retail internationalisation within a business model conceptualisation we can identify the different relationships and activities relevant to a retail business and begin to understand how these influence, and are influenced by, different categories of embeddedness and related processes.

First developed formally in the late 1950s and early 1960s, the concept of a firm's business model became a popular topic in the business literature in the late 2000s (for example Amit and Zott, 2002; Magretta, 2002; Hedman and Kalling, 2003; Afuah, 2004; Giesen et al., 2007; Chesbrough, 2007, 2009; Johnson et al., 2008; Richardson, 2008; Casadesus-Masanell and Ricart, 2010; Dunford et al., 2010). Most definitions refer to a business model as being the logic by which an organisation creates and delivers value (Osterwalder and Pigneur, 2010; Zott and Amit, 2010; Baden-Fuller and Morgan, 2010; Sorescu et al., 2011; Bock et al., 2011; Zott et al., 2011). Casadesus-Masanell and Ricart (2010) distinguish between the business model, which they consider as the logic of the firm, the way it operates and how it creates value for stakeholders; business strategy, which involves the choice of business 
model through which a firm will compete; and business tactics which entails the choices open to the firm in applying the business model. They conclude that a "business model is a reflection of a firms realized strategy" (p96; original emphasis).

Sorescu et al (2011) take a more integrated view and invoke a role for stakeholders other than the firm. As such, this definition is more useful for considering firm level behaviour:

"A business model is a well-specified system of interdependent structures, activities and processes that serves as a firm's organizing logic for value creation (for its customers) and value appropriation (for itself and its partners)" (Sorescu et al, 2011: p54)

With this definition it is possible to consider what comprises a business model and how the concept of embeddedness relates to it. Osterwalder and Pigneur (2010) provide a generic framework comprising nine elements commonly found in the business model literature (Figure 2). These elements are grouped into i.) value proposition; ii.) customer facing elements; iii.) resource and infrastructure elements; iv.) financial elements. The model is embedded in an institutional environment that influences its application.

Central to the business model is the value proposition or offer. This is aimed at satisfying customer needs and values, and comprises the bundle of products and services provided by the organisation. This represents the value creation purpose of business activities. Three elements of the framework can be viewed as customer facing: customer segments, which identify who value is being created for; customer relationships, including service activities and interactions with customers; and channels, determining how customers are reached and how channel activities are integrated and managed. The resource and infrastructure elements, sometimes termed the 'eco-system', comprise: key resources, which are both human and financial, and may be physical or intellectual; and key activities, which consider how resources are applied to provide the value proposition. These resources and activities involve partnerships - the networks, alliances and inherent interactions and behaviours necessary to leverage the value proposition. The final consideration is the financial relationship between the income generated by revenue flows arising from the customer facing elements and the costs of managing the resources and performing the activities to deliver the value proposition. 
Figure 2 : The Osterwalder and Pigneur Business Model Framework

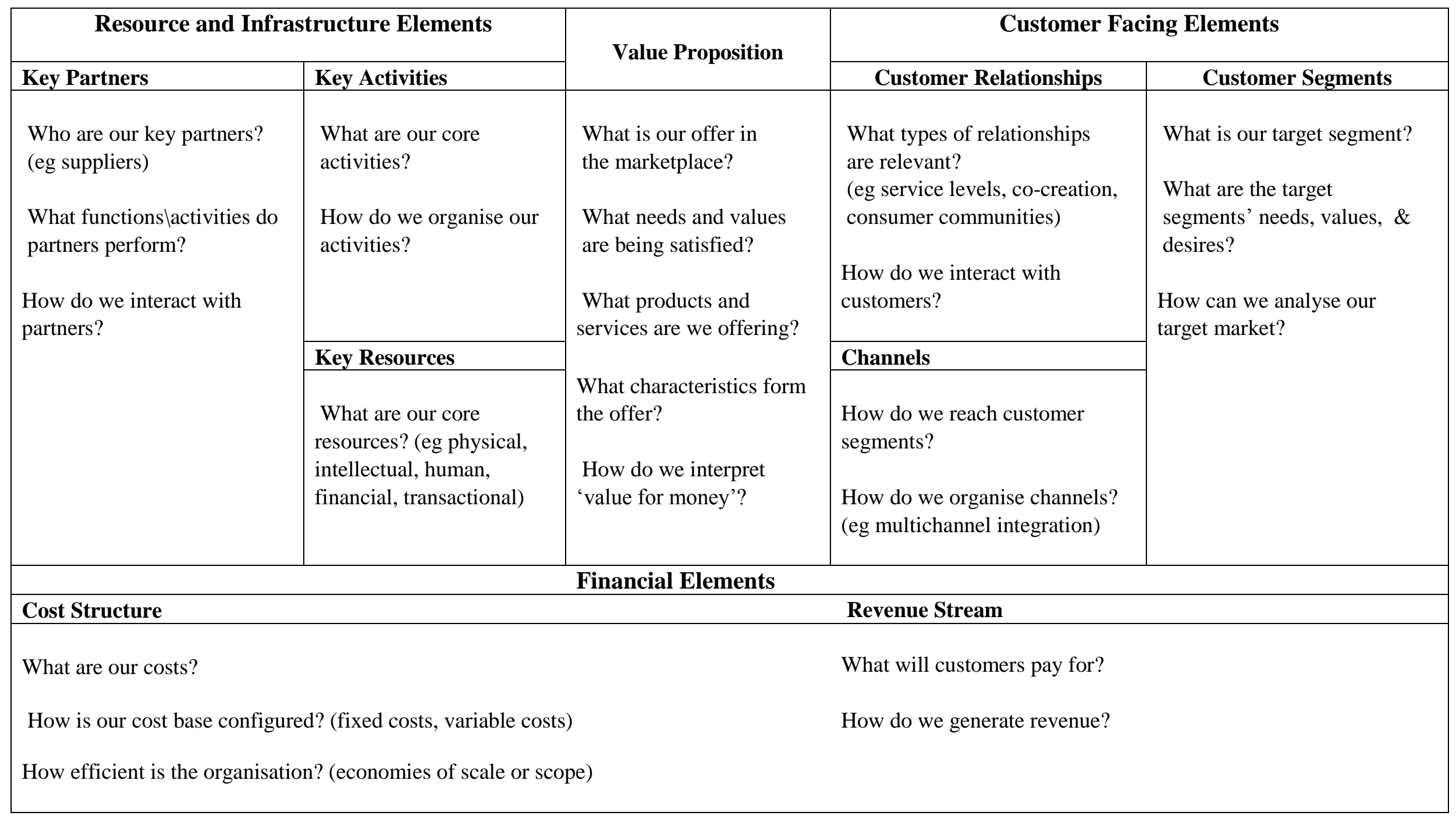

Adapted from Osterwalder and Pigneur (2010) 
Applying a generic business model to retailing requires consideration of whether there are particularities associated with retailing: such as the mix of products and services, the need for vertical and horizontal coordination, and the numerous daily face to face transactions etc. (Dawson, 1994, 2007), that should be accommodated in the model. One common component of business model conceptualisations is the idea of output - in effect the execution of the value proposition in the Osterwalder and Pigneur framework. There has been considerable debate over several decades (for example McClelland, 1966; Douglas, 1975; Bucklin, 1972; Achabal et al., 1985; Betancourt, 2004; Dawson, 2005) over what constitutes output in the retail sector. Dawson and Mukoyama (2014) suggest that the output of the retail business is the 'place of transaction'. This is an extension of the established concept of the retail format and may be a physical store (for example hypermarket, department store, boutique) or a virtual place (for example on-line retailing). In creating a 'place of transaction' the retailer also interprets a format concept to create its own retail formula(e). The formula is the execution of the value proposition that is specific to a retailer via a range of activities, relationships and behaviours, and thus encapsulates the competitive advantage of that retailer. Through a specific combination of retail format and retail formula, international retailers present themselves differently to customers in different markets.

An important way of distinguishing and identifying a specific retail formula to consumers is through branding. The retail brand is concerned with packaging the benefits and value(s) that a retail formula creates for consumers and is a means of communicating these values. The brand makes overall promises to customers about what value(s) the format and formula can deliver (low prices, convenience, status, etc.). The retail brand is a fundamental part of a retailer's value proposition (Burt and Davies, 2010). International retailers may employ brand extension strategies to communicate similar underlying values across a range of formats and formulae, or multiple branding strategies to distinguish at one level between different formats (eg convenience store, supermarket, superstore) and at another level between different value propositions encapsulated within formula (eg the approach of Inditex, H\&M etc.). When employing the Osterwalder and Pigneur framework in the context of retailing, considerations of the format, formula and brand should be incorporated.

For a business model to be effective it has to exist within a form of governance. Sorescu et al., (2011) suggest that governance is one of three distinct components of a retail business model. Whilst form of governance is not explicit in the Osterwalder and Pigneur framework it is important in international retailing with multiple governance systems possible as a 
retailer moves into new markets. The governance of the different business model activities can be performed by a number of actors. The retail firm may perform all of the activities within the business model itself: it operates and manages all the shops, sources and possibly manufacturers the products, employs all personnel, and develops and maintains all necessary resources (production, people etc.). In this case, the governance of the retailer is highly integrated. Alternatively, the retail firm may own and operate some aspects, maybe only the brand, and outsource other activities. In this situation governance is highly networked. There are many intermediate types of governance between these extremes. Governance issues need to be considered in the Osterwalder and Pigneur framework for it to be useful in considering international retailing.

The Osterwalder and Pigneur conceptualisation of the business model focuses on the internal structure and agency of the firm. The application of the business model occurs however in an instituted market that has characteristics, notably the regulatory framework, market structure, and competitor set, that encourages or constrains how application occurs, and impacts upon embedding processes. Institutional factors are external to the business model but nonetheless affect it. In international retailing these institutional factors may be very different in the various markets in which the retailer operates and thus the application and embedding of the business model may be institutionally constrained or encouraged differently in the various geographies involved. Retailer internationalisation can thus be seen as the convergence of the processes of transfer, negotiation and adaptation associated with the different categories of embeddedness, with the activities involved in operationalising the various components of the business model.

In the context of international retailing we can use an extended version of the Osterwalder and Pigneur business model framework, incorporating retail specific elements of format, formula and brand to the value proposition and governance considerations into key activities and relationships to consider how the business model becomes embedded within the various markets in which the retailer operates.

\section{The IKEA Case}

We use the case of IKEA to illustrate the interaction of a retailer's business model with the concept of embeddedness in the retail internationalisation process. A single case study 
approach is used in order to provide depth to the analysis within the space constraints of an academic paper. The single case study approach is widely accepted as a valid research design for this type of study (George and Bennett, 2005; Yin, 2009; Tokatli, 2014).

IKEA has a history of multi-continental internationalisation, thus providing a wide range of geographical contexts. Having first moved into Switzerland (1973) and Germany (1974), by the start of 2015, there were 365 IKEA stores in 47 countries. IKEA has been the subject of numerous studies ranging from PhD theses (for example Mårtenson, 1981; Salzer, 1994; Jonsson, 2007; Tarnovskaya, 2007; Cassinger, 2010), academic papers (for example Mårtensen, 1987; Laulajainen 1991; Jonsson, 2008; Johansson and Thelander, 2009; Burt et al., 2011a,2 011b), business school teaching materials (for example Beamish, 1988; Bartlett and Nanda, 1990; Moon, 2004; Bartlett et al., 2006; Barthélémy, 2008; Huy et al., 2011), case illustrations in international marketing texts (for example Barlett and Nanda, 1988; Terpstra and Sarathy, 1990; Czintoka and Ronkainen, 1990) and books (Torekull, 1998, 2006; Lewis, 2005; Edvardsson and Enquist, 2009; Stenbo, 2010; Dahlvig, 2012). Throughout most of this material IKEA has been characterised as a 'global retailer', with a standardised operating ethos and the same market position worldwide.

We draw on this extensive academic literature, company materials and documents, and a programme of interviews with IKEA executives at Head Office and in selected country markets, including the UK, China, USA, Japan and Australia. In total 25 executives were interviewed, some more than once. Interviews were conducted in Swedish and English, varied in length between 1-3 hours and were recorded. The interviewees were all, with a few exceptions, senior managers with considerable leadership experience in IKEA. All were working in the retail business, in positions where they could influence and define business strategy at country, region and in some cases Group level. Those interviewed, therefore, had an overall grasp of the IKEA business model, rather than just specific operational functions. Anonymity was promised, hence quotes are not attributed to individual respondents.

In the following discussion we utilise the Osterwalder and Pigneur business model framework to explore for IKEA the three categories of embeddedness identified by Hess (2004). We consider the different elements of the business model sequentially through the three lenses of societal, network and territorial embeddedness. Some activities in the business model reflect more than one form of embeddedness so the forms of embeddedness are not 
totally discrete but are sometimes interlinked to create the totality of the embeddedness of IKEA in its local market.

\section{Societal Embeddedness: identifying and transferring the genetic code}

Societal embeddedness is reflected in the historical foundations of the retail organisation. This creates a 'genetic code' which underpins the core business model for IKEA (Figure 3). When a retailer internationalises, moving from the home market where the business model evolved into a new market, the extent to which the core business model transfers becomes a fundamental issue. In broad terms, IKEA seeks to transfer most elements of the underlying business model into new markets. A long established value proposition, is reinforced by a strong corporate culture, specific governance systems and a uniform approach to customer relationships and channels. The core business model is, however, not fixed over time and space, and evolves as embeddedness processes occur. Retailers are 'living' organisations with behaviours, interpretations and attitudes built up within an organisational context over a significant period of time. As retailers interact with diverse socio-political-economic environments, their business activities, processes and outputs evolve.

\section{The Value Proposition}

IKEA's target customer group is the mass market and the provision of good quality furniture of Scandinavian design at an affordable price. IKEA's value proposition follows closely from the formulation of the original business idea:

"The IKEA vision is to create a better future for the many people. This is made possible by offering a wide range of well-designed, functional home furnishing products at prices so low that as many people as possible can afford them" (www.IKEA.com)

Lindqvist (2009) argues that the origins of the IKEA proposition lie in a Swedish cultural narrative and the functionalist style, often referred to as the 'Swedish modern' movement. She dissects various elements of the 'cultural archive' and symbolism of the IKEA store which she suggests: "helps to construct, reproduce and disseminate a narrative of Swedish exceptionalism worldwide”.(p43)

Internally, the 'Testament of a Furniture Dealer' issued in 1976 by the founder, Ingvar Kamprad, formalised and codified IKEA's cultural values and operations (Tarnovskaya et al., 
Figure 3 : IKEA - Societal Embeddedness

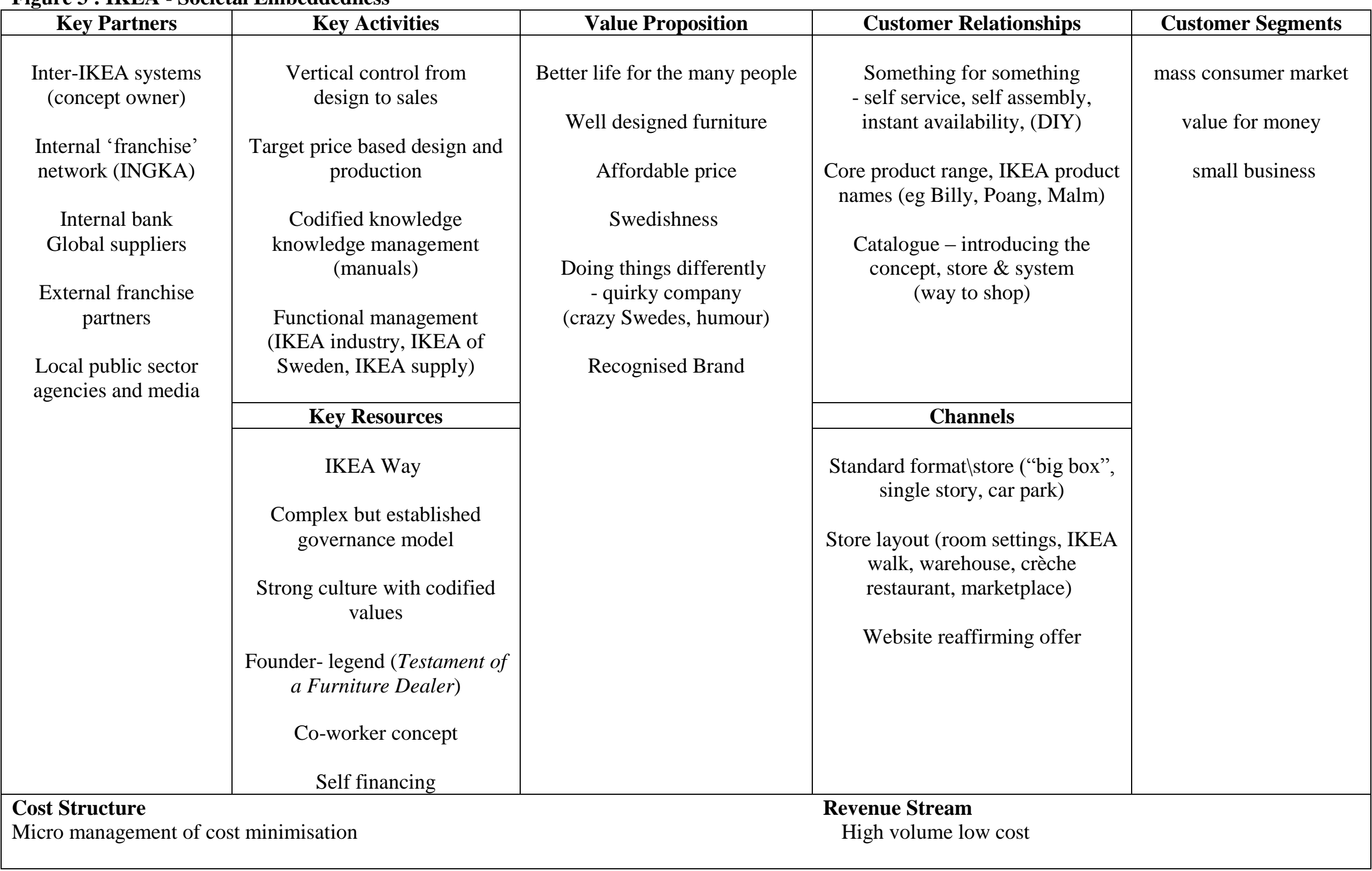


2008; Tarnovskaya and de Chernatony, 2011). At the core of the 'Testament', and of the IKEA proposition, are the product range, design principles, different ways and means to create more with fewer resources, being different, and doing things in a different way. The value system was reinforced further in 1996 through the addition of 'a little dictionary' to the second edition of the 'Testament'. This incorporated words and phrases linked to IKEAs heritage and commonly used in-house to articulate its values and behaviours (Edvardsson and Enqvist, 2009).

The underlying importance of its Swedish cultural origins to the IKEA value proposition were similarly summarised by one respondent:

"IKEA comes from Sweden and that is something that is carried through as an important part of our DNA to every market in the world where IKEA operates. Blue and yellow are the colours of the Swedish flag, the same colour as the store's exterior. Småland is the particular part of Sweden where IKEA has its origin but I think it is more general Swedishness that is the backbone; frugal, trustworthy, down to earth, straightforward and democratic" (interview respondent)

\section{Consumer Facing Elements}

The value proposition is delivered to the 'many people', through a range of societally embedded customer facing elements ingrained in IKEA's genetic code. The focus on cost minimisation yielding low prices is underpinned through the 'we do our part, you do your part' DIY formulation evident in several aspects of customer relationships and engagement. IKEA provides the product in the store, and then customers have to complete a number of tasks (selecting, picking, transport and assembly) to maintain low prices.

Reinforcement of the cultural origins of IKEA is important in emphasising the individuality of the brand (Lindqvist, 2009). The 'Swedishness' of the proposition is reinforced through the product range, which carries Scandinavian names. Beds, wardrobes and hall furniture have Norwegian place names; sofas, chairs, stools and tables have Swedish place names; and rugs have Danish place names. For other parts of the assortment, occupations, children's names, and animal names are used. The children's crèche is named 'Småland'- the region from which IKEA originated, and also a land for children (small people) - and in every store there is a food-shop offering Swedish food specialities, further embedding the Swedishness of the concept. 
The iconic catalogue, which first appeared in 1951, is a major component of the IKEA customer relationship. The basic design of the catalogue, translated into 30 languages and produced in 217 million copies, is similar for all markets with adjustments made to reflect race and ethnicity:

"The IKEA catalogue is part of our heritage and what makes IKEA special .... I recognise that in some parts of the world due to population density, new media, culture etc the catalogue needs to be modified and changed to fit more to a market ... Also, while it may seem a little stone age, it is something that differentiates IKEA from competitors. Who has resources to create and maintain one of the biggest printed original products in the world?" (interview respondent)

In retailing, the store format and formula are the means of making the offer available. The ideal IKEA concept is a single store format comprising around 30,000 square metres of floorspace on two floors, typically located outside the city centre, with a large parking lot. Externally the IKEA store is highly visible with the blue and yellow colours of the Swedish flag. Inside, customers are first directed to the upper level containing furniture displayed in room settings typical to that market plus the restaurant, they are guided via floor markings through product displays until descending to the lower level containing smaller home furnishings (referred to as the market hall), the storage for the self-service products (the warehouse) and checkouts. Also on the lower floor are the Swedish food shop, the Småland crèche and the information desk where additional services can be purchased or merchandise returned. The design concept behind this store layout is central to IKEA's cultural existence. Regular commercial reviews provide audits of consistency and adherence to the core concept across countries and stores (Jonsson and Kalling, 2007). This represents a vigorous transfer process creating a societally embedded, but evolving, concept that is then the subject of network and territorial embedding into disparate markets where some adaption takes place.

\section{Resource and Infrastructure Elements (Eco-System)}

IKEA has established an internal network of organisational units designed to implement the IKEA concept. In the early 1980s the Group was reorganised to separate the retail concept from the retail operation. The Inter IKEA Group, ultimately owned by the Leichtenstein based Interogo Foundation, was formed to "ensure continuous improvement and a long life of the IKEA concept". This separation was intended to protect the IKEA concept and provide financial independence allowing investment in both "good and bad times". Consequently all stores are now franchises of Inter IKEA Systems which owns the IKEA concept and a pilot 
store in Delft. All stores pay a franchise fee of 3\% of sales to Inter IKEA Systems for use of the concept. As the concept holder, Inter IKEA Systems acts as the 'overseer' responsible for five tasks: expansion via franchising; improving the concept; transferring know-how to retailers and monitoring and protecting the concept. Inter IKEA Systems operates across all markets. This governance structure is transferred into new markets and controls any expansion in existing markets.

"Among international retailers I think we will see a trend towards a different ownership structure than the traditional limited company. It does not have to be the way we have set it up in IKEA but it needs to be a structure that has more patience than delivering a profit the next month." (interview respondent)

The retail operations are independently managed by the IKEA Group (INGKA Holding and subsidiaries), which is the main franchisee. INGKA which was formed as a vehicle into which stores were transferred when the franchise system was set up, operates the majority of stores (318), with a further 12 external franchisees operating the remainder (46). The IKEA Group also provides functional management for the organisation including production (IKEA Industry, previously Swedwood, which operates 44 production units in 11 countries); purchasing and logistics (IKEA Supply); product and range development (IKEA of Sweden); food services and retail store operations.

Processes and systems are designed to reduce costs and to keep prices low. The principle of target pricing drives a process approach underpinning all of IKEA's activities. Product development and sourcing policy starts with a target sales price, and then activities are managed to source the product at that price (Torekull, 1998). Every product is deconstructed. By taking into account not only the functioning of the product but also the ease of packaging, transportation and assembly, standardised processes and systems deliver lower costs throughout the supply chain, as well as potentially leading to easier assembly by customers.

IKEA's concept is transferred through formal codification in manuals detailing how things are done and how to stay true to the IKEA concept. Circa 75 manuals act as vehicles to transfer values and embed them in the host markets. Jonsson $(2007,2008)$ identifies three types of knowledge important to maintaining the IKEA concept: corporate knowledge - how IKEA works and behaves; market knowledge - insights from the markets in which it operates; and internationalisation knowledge - expertise in how to enter and develop new markets. Formal and informal knowledge management and knowledge sharing mechanisms 
(Jonsson and Elg, 2006; Jonsson and Kalling, 2007; and Jonsson and Foss, 2011) are important internal elements in brand and culture transfer.

One of the key soft resources in any organisational business model is organisational culture. This is grounded in the societal embeddedness of the organisation. One way to make a brand a living concept is through establishing a core set of corporate values and spreading these throughout the organisation (Salzer, 1994). This has been fundamental to the development of an IKEA organisational culture. At the heart of IKEA's corporate value set is the 'Testament' and the associated efforts made to educate employees (known as co-workers) and suppliers about IKEA's business ethos through the 'IKEA Way' (IKEA, 2003). The 'IKEA Way' emerged from a project launched in 1979 when it was felt that the company was becoming too decentralised in range management and buying decisions. It has become the foundation training programme for managers, and is usually held at Älmhult (the birthplace of IKEA) where a number of central office functions including IKEA of Sweden (the product development function) are still located (Lindquist, 2009). The maintenance of a formal connection with the 'spiritual home' reinforces the social and cultural origins of the business model. In a small town of circa 15,000 inhabitants, the presence of 2,500 IKEANs dominates life (Baraldi, 2003)

The societal embeddedness of IKEA in Sweden is profound and far reaching. The strength and clarity of the business model is a major factor in establishing societal embeddedness. In becoming an international retailer IKEA has transferred the strengths of the business model to other markets and has used the leverage of the transferred model via the processes of network and territorial embeddedness to gain societal embeddedness in the new markets. This transfer of societal embeddedness is a foundation for the internationalisation strategy. Aspects of the business model are transferred directly into the markets when IKEA enters and then provide a framework that defines the conditions for development in the market. The transfer of knowledge and values is a core process in creating societal embeddedness.

\section{Network Embeddedness: negotiating and shaping relationships and behaviours}

Figure 4 provides examples of network activities in the business model as network embeddedness occurs. As a retailer internationalises the networks of and relationships with partners in the value chain change. IKEA negotiates relationships and behaviours across its 
networks in new markets. Networks and relationships occur on a number of spatial levels ranging from the global to the local, and include non-spatial relationships.

\section{Value Proposition}

Network embeddedness in both the global and local context tends to reinforce the underlying value proposition via negotiating and shaping customer facing and resource and infrastructure elements. Market information from the developing store network informs the evolution of the value proposition and increases the embeddedness of the store network. The clarity of the value proposition, alongside the reputation of IKEA as a brand provides distinctiveness in the marketplace and the opportunity to negotiate existing ways of operating in the marketplace

\section{Consumer Facing Elements}

Engagement with customers in different markets is broadly the same reflecting the desire to transfer the underlying, societally embedded, business model. The target customer group remains the mass market and the way customers 'shop' an IKEA store remains the same, although in some markets the process requires more direct explanation at least in the initial entry stages. However, activities (and core relationships) $r$ evolve over time. For example, although existing in various forms since the mid 1980s, the IKEA Family loyalty scheme was only formally launched in 2005 in Sweden, Denmark, Austria, France, Germany and Italy, and became more widely available by 2007 . The scheme provides discounts and other benefits to members, reinforcing relationships and strengthening ties to IKEA by encouraging visits (and spend) in store and on the web (Edvardsson and Enqvist, 2009)

As the model of consumer engagement evolves, established elements of the customer relationship become renegotiated; shortcuts are provided in store to allow customers to deviate from the pathway, information and pictures of product designers are provided to reiterate the design element of the proposition, room setting ideas rather than products dominate the catalogue, and services change and evolve.

The core elements of the store format and formula remain the same and customer relationships within national markets are further reinforced as a chain of stores is built and becomes embedded as a network in the market. The establishment of a chain of stores in a market is an important aspect of the business model, contributing to scale economies in store operations, for example in advertising, and in sourcing and supply chain operations. The 
Figure 4: Network Embeddedness in IKEA

\begin{tabular}{|c|c|c|c|c|}
\hline Key Partners & Key Activities & Value Proposition & Customer Relationships & Customer Segments \\
\hline $\begin{array}{c}\text { Globallocal supplier mix } \\
\text { Trading Office network } \\
\text { Internal network of designers } \\
\text { Public sector agency relationships } \\
\text { Local agencies for adverts } \\
\text { Competitors who copy IKEA } \\
\text { (by default strengthen IKEA) }\end{array}$ & $\begin{array}{c}\text { Key Resources } \\
\text { IKEANS - expatriate oversight } \\
\text { (corporate and internationalisation } \\
\text { knowledge) } \\
\text { Systems } \\
\text { Employee training } \\
\text { Organisational culture } \\
\text { The network that links the stores } \\
\text { into a 'chain' }\end{array}$ & $\begin{array}{c}\text { Reinforced as the store } \\
\text { chain develops in the } \\
\text { market }\end{array}$ & $\begin{array}{c}\text { Similar proposition } \\
\text { (DIY, format, formula) } \\
\text { IKEA Family loyalty } \\
\text { scheme } \\
\text { Distribution network for } \\
\text { catalogue } \\
\text { Relationships through the } \\
\text { chain of stores } \\
\text { “event” of store opening } \\
\text { Channels } \\
\begin{array}{c}\text { Role of Website and App in } \\
\text { supplementinglreplacing } \\
\text { catalogue }\end{array} \\
\text { Establish key, high } \\
\text { visibility, store locations }\end{array}$ & $\begin{array}{l}\text { Mass consumer market } \\
\text { Value for money } \\
\text { Inter-changeability of } \\
\text { stores in network }\end{array}$ \\
\hline \multicolumn{3}{|c|}{$\begin{array}{l}\text { Cost Structure } \\
\text { Micro management of cost minimisation }\end{array}$} & $\begin{array}{l}\text { Revenue Stream } \\
\text { High volume low cost }\end{array}$ & \\
\hline
\end{tabular}


creation and embedding of the store network is also important for customer relationships providing an opportunity to reinforce relationships with each new store opening which are major events in the locality. Furthermore from a consumer perspective as the store network develops so awareness of IKEA increases, consumers become more aware of the differences from existing market offerings, and become more literate in reading and understanding IKEA as a concept. The embedding of the chain store network is an important aspect in the negotiation between IKEA and consumers about the values on offer and the values gained in the customer relationship.

\section{Resource and Infrastructure Elements (Eco-System)}

In considering IKEA's entry into Russia and China, Ford et al., (1998) discuss the importance for retailers in particular, of having good relationships with the network of key stakeholders in these markets including local suppliers, political actors, bureaucrats, interest groups and the media, to create a position in the marketplace. Networking capabilities become a key organisational asset as does the ability to integrate resources at the different spatial levels (global, macro and micro) of the network in which IKEA operates.

IKEA's strategy of sourcing from low-cost countries to reduce prices emerged in 1961. IKEA was frustrated by Swedish furniture manufacturers who, under pressure from other retailers, refused to sell their products through IKEA. The response was to develop contacts in Poland and the IKEA global sourcing strategy was born. Although production costs in Central Europe were low, technical upgrading was required so an approach that fostered supplier development emerged. This took the form of long term negotiated strategic commitments (Baraldi, 2008; Ghauri et al., 2008), which increased network embeddedness for example in the Polish transitional economy of the 1990s (Dawson, 2001). Sourcing has always focused on large volumes of standardised products to maintain low prices, however, a recent trend is a return to local (regional) market sourcing due to increasing costs and lengthening lead times (Ivarsson and Alvstam, 2010). The increase in chain scale at regional level enables purchasing economies to be negotiated at that level. Regional offices increasingly source within their own regions, reducing distribution costs, and responding to environmental agendas. This move to regional sourcing involves regional embedding of the network of suppliers rather than centralised global sourcing.

"One central part of the IKEA business model for a long time has been centralised sourcing, meaning that rather than sourcing locally, you centralise sourcing and buy 
big volumes that you then ship to the different markets around the world. In the case of China we understood fairly quickly, ... that sending the products around the world would not be a very good solution. Sending stuff from Eastern Europe to China could take for ever with Chinese customs and transport times, adding costs in a market where we had to slice cost to get the Chinese to buy in our stores not just look around in the store. So we had to look for local suppliers, we had started doing through our buying office before we opened the Shanghai store but with that store in operation that work had to intensify. In order to maintain a low enough price level in China we source more locally here than for any other market in the world" (interview respondent)

Whilst IKEA of Sweden retains a pivotal role in providing a strategic oversight of the development, purchase, distribution and marketing of products within the range, it is supported by a network of Trading Offices, Distribution Centres, logistics partners, suppliers and sub-contractors. Representatives from IKEA's Trading Offices are charged with finding new suppliers in their respective markets as well as developing personal relationships with existing suppliers. Rationalisation of the supplier base has occurred, from around 2,300 suppliers in the mid 1990s and 1,400 in the mid 2000s, to 1,002 suppliers in 51 countries in 2015 .

Overall, IKEA's technological support to suppliers is extensive. Ivarsson and Alvstam, (2010, 2011) distinguish between on-going, regular support via IWAY (IKEA way on purchasing home furnishing products) and QWAY (IKEA Supplier Quality Assurance Programme), and longer-term strategic support. The IWAY code of conduct, implemented in 2000, is in effect a CSR policy, detailing standards and principles that suppliers must adhere to (IKEA Supply AG, 2008). All IKEA suppliers must comply with IKEA standards, national laws, and international conventions on basic working conditions, child labour and other social and environmental conditions. Suppliers also have to prepare action plans for meeting these criteria (Edvardsson et al., 2006; Jonsson and Foss, 2011; Tarnovskaya, 2007). Regular supplier support includes provision of product designs and technological specifications, feedback on product performance, support to improve existing technology, and training programs etc. Strategic support involves technical consultation on product characteristics to master new technology; advice on production layout and organisation; and advice or financial assistance to obtain raw materials, components and equipment. This strategic support requires IKEA to negotiate a deep embeddedness into the supplying firms. 
Relationships with supplier networks are not the only ones that need to be negotiated in the host market. Each IKEA store is akin to a medium-sized business with 400-600 employees serving millions of customers every year. Consequently a new IKEA store usually has a huge local impact on traffic, road networks, and infrastructure (Hrelja et al., 2012). Pütz (2011) highlights the competing goals and objectives, and power and governance relationships at play when such a large and visible investment is under consideration. Negotiations with public agencies for planning permission affects the speed with which the store network can be embedded into the market and may entail adjustments to the store format, such as multilevel stores taking up less space as in the UK. In this case activities to enhance network embeddedness operate alongside those of territorial embeddedness associated with the institutional environment.

\section{Territorial Embeddedess: anchoring and adapting the business model in place(s)}

The concept of territorial embeddedness has been the main focus of previous studies of retail internationalisation. In the case of IKEA, the issue to consider is the extent to which territorial embeddedness has influenced the original genetic code of the business model or the extent to which the retailer has, itself, shaped behaviours in the host market (Figure 5).

\section{Value Proposition}

The fundamental value proposition is maintained as far as possible within local markets. One might argue that the general approach is to minimise territorial embeddedness with respect to the underlying value proposition. The ideal is to create 'IKEA in Japan' rather than 'IKEA Japan'.

"If you let every IKEA country in the world create their own national specific IKEA, the business model and hence the competitive advantage of IKEA would be lost. Sounds simple? It is an everyday struggle to maintain this because it means constantly saying no to initiatives in the different markets as it would in the end erode the business model" (interview respondent).

Nonetheless the concepts of value and design differ across the major culture realms. For example, the interpretation of 'value for money' has to be nuanced to accord with local levels of spending power, with IKEA products being more aspirational in lower income markets. This was evident in Poland in the early 1990s and is also seen in China this century. 


\section{Consumer Facing Elements}

Although in all its markets IKEA aims for the mass market (the many people) in some markets socio-economic conditions result in a changed reciprocity between the value proposition and target consumer segments. In China for example it is extremely difficult for IKEA to offer 'affordable prices'.

"When we had decided to enter China, I went there several times in the build up. I also went there quite close to the opening of the first store with the mission of trying to get some grasp on what price level we were going to use in China. But that was not an easy task as there was - you have to remember that this was in 1998 when the market looked very much different from the way it looks today - nothing to compare with. And then I mean there were no other big-box retailers present that could give us a hint as to what price level would be suitable. All the competition was local and could not be used - at least that is what I thought-as guidance for what prices to set. So we ended up setting prices based on what we thought would be right. And of course, we put exactly the wrong prices on everything as we came from markets where the living standard was so much higher and it is very easy to find price references." (interview respondent)

Products are easily copied and versions offered at lower prices which IKEA cannot match. Additionally Chinese consumers associate foreign brands with high prices and high quality. Although IKEA promotes a lowlaffordable price position, this price level is beyond the mass of the market and the message creates confusion. Consequently in order to be embedded, the target customer segment in China emerges as the younger, predominantly female, middle class rather than the intended 'many people' (Wei and Zou, 2007).

Similarly when establishing stores in China and returning to Japan IKEA recognised that the underlying DIY concept was alien in Asian markets:

"There where so many things that were different about China and the Chinese market, and we did some very classical mistakes and the most apparent was assuming that it is the same in China as it is in Europe. .... it turned out that most households do not own a screwdriver, let alone have any skill in assembling furniture. If you needed to do something like that in your home in China, you hired someone to do it for you rather than do it yourself." (interview respondent)

This disconnect is further reinforced when the furniture is perceived as being an 'expensive' foreign brand. Indeed, the entire IKEA shopping experience was alien: walking around a store, selecting and carrying away things themselves, and then transporting purchases home and assembling them. IKEA have always argued that the core DIY concept is sacrosanct as it 
Figure 5: Territorial Embeddedness

\begin{tabular}{|c|c|c|c|c|}
\hline Key Partners & Key Activities & Value Proposition & Customer Relationships & Customer Segments \\
\hline $\begin{array}{l}\text { Local suppliers to allow } \\
\text { local prices } \\
\text { Trading Offices } \\
\text { managing supplier } \\
\text { development }\end{array}$ & $\begin{array}{c}\text { Key Resources } \\
\text { Use of IKEANs to } \\
\text { transfer knowledge } \\
\\
\text { HR policy engaging } \\
\text { locals - local market } \\
\text { knowledge }\end{array}$ & $\begin{array}{c}\text { Affordable } \\
\text { Swedishness } \\
\text { Recognised Brand } \\
\text { But with awareness of } \\
\text { local socio-economic } \\
\text { - cultural sensitivities }\end{array}$ & $\begin{array}{c}\text { Catalogue adaptation -smaller } \\
\text { range based (eg kitchens) } \\
\text { Localised communication } \\
\text { themes (eg explain concept) } \\
\text { Variations to product range from } \\
\text { core range } \\
\text { Some services (delivery, } \\
\text { assembly) introduced } \\
\text { Channels } \\
\text { Store adaptation } \\
\text { - locally relevant room settings, } \\
\text { different price position, } \\
\text { multi-level store format, } \\
\text { in-citylurban area locations }\end{array}$ & $\begin{array}{l}\text { Characteristics of customer } \\
\text { segments may vary } \\
\text { (eg with income) } \\
\text { Consumer perceptions } \\
\text { (eg value for money, } \\
\text { foreignness) }\end{array}$ \\
\hline $\begin{array}{c}\text { Cost Structure } \\
\text { Micro management of cost }\end{array}$ & inimisation & & $\begin{array}{l}\text { Revenue Stream } \\
\text { High volume low cost }\end{array}$ & \\
\hline
\end{tabular}


is so central to the IKEA value proposition. However, in China changes were needed to embed the concept in the local market and gain customer acceptance. These changes included introducing transportation, delivery and assembly services. At first these were offered free of charge but later fees were introduced. Many of these services are now offered in other IKEA stores around the world.

The addition of customer services in some markets is an illustration of the adaption of the standardised concept in order to generate territorial embeddedness. IKEA claims that most elements, for example the store, products and catalogue are highly standardised, and it is mainly with respect to the local (in-country) communication where most adaptation is seen. Although there are certain guidelines over what to communicate in relation to the IKEA brand concept, it is accepted that local management needs to find ways to make the brand relevant in the local market. This is most evident in the local advertising and marketing activities:

"IKEA has the same value proposition around the world, basically we say the same things to customers living here in Sweden as we say to consumers living in Tokyo or in Shanghai. But we need to say it in different ways that works in different cultural settings. The tone of voice in equal minded Sweden need to be different from that used in hierarchical Japan." (interview respondent).

Although the basic template for every IKEA store is the same, there are also adaptions that generate territorial embeddedness. The five room settings that greet the customer on the second floor provide a local feel. One dimension to this is that they should be the same size and set up of a 'normal' house/apartment in that market, giving customers a feel for how IKEA can help in terms of furnishing a typical home. Accordingly, the room settings differ by market.

“...., in China and especially in Shanghai you will find a set-up of how to furnish our balcony with IKEA furniture, in the UK, many room settings will have a mantle piece reflecting that many UK homes have fireplaces, in the Osaka store in Japan you will find an earth quake beam going straight through the living room, reflecting the living space for many Japanese, in Australia the room settings are very large and have large furniture due to the fact that the Australians have the biggest living space of all." (interview respondent)

The room settings are refined and further adapted as territorial embeddedness increases.

Other examples of territorial embeddedness are found in the product assortment and catalogue. Whilst the general assortment of an IKEA store is the same around the world - 
comprising around 9,500 items of which approximately 2,000 are new products introduced every year (Ivarsson and Alvstam, 2010) - not every store in every market carries every product. There is some range variation to reflect the local market. For example, in the USA beds had to be described as 'king', 'queen' or 'twin' rather than by dimensions, and some sizing issues also arose with kitchenware items originally deemed to be too small for American tastes; in Asia the largest PAX wardrobe systems are not part of the offer, as they would not fit into a normal sized apartment; and in Russia sofa-beds feature more prominently to maximise usable space in the home. In these markets, local management will choose those parts of the IKEA assortment that fit the design and size of homes in their respective markets. However, no unique market specific products are added to the range. All products have to be part of the core IKEA assortment. The rationale is that by keeping to an 'IKEA' branded assortment and not adding other products, there is a unique product offer which remains distinctive. The emphasis on being different from local competition but also being the same everywhere is an important feature of customer interaction in IKEA. This results in some constraints on the extent to which adaption and territorial embeddedness can occur.

The catalogue is a core element in customer relationships and is available in all markets. However, the practicalities of distributing it to large numbers of households, particularly in very densely populated markets, entails some adjustment to the catalogue distribution strategy. Abridged catalogues may be distributed to reflect the local neighbourhood structure.

\footnotetext{
"International expansion is always a battle between sticking to what got you thereand changing and adapting when expanding. Take the IKEA catalogue in China. Without the tradition of post-boxes and being over a billion people-and more than the combined population of the Nordic countries in the Shanghai area - the catalogue as a +100 pages print matter maybe is not the smartest marketing tool in that part of the world, while it is the marketing tool in Europe. Still there is a way to adapt here; the catalogue in China is much thinner and distributed mainly through the stores and not individual mailboxes" (interview respondent)
}

The advent of the internet and mobile technologies has changed the relationship between the store and catalogue. These channels provide alternative or complementary options for customers to view the product range and gain décor ideas and may prove to be more appropriate and cost effective in some markets: 
"New and expanding markets like China are interesting and challenging for a company like IKEA that have certain standardised ways of doing things. For example, in China the Internet as an information channel and distribution channel is much more important earlier than in other IKEA markets. So it is always a balance between imposing how we do things on a market and adapting" (interview respondent)

\section{Resource and Infrastructure Elements (Eco-System)}

Ghauri et al., (2008) and Elg et al., (2011) discuss how IKEA develops its local supplier base in markets such as Poland and Russia. Activities range from explaining the vision and key core values, applying new technological solutions, to assisting on HR issues and joint product development. In Poland, IKEA also have local business developers in place to develop local suppliers (Project Push Poland). Deligonul et al., (2013) discuss IKEA's work with suppliers in Poland and Russia, from the perspective of institutional theory, and conclude that from IKEA's perspective, developing suppliers in these markets adds to IKEA's legitimacy as a company. Baraldi (2008) highlights the local importance of the Trading Office in supplier development and discusses the strengthening of relationships with local suppliers through a three step ladder model, commencing with a 'Call-off' system, a market-like system and order fulfilment relationship with IKEA placing orders every four weeks to be delivered within the next four weeks; and ending with a Vendor Managed Inventory (VMI) relationship in which suppliers have access to the IKEA inventory system and manage IKEA stores inventories themselves, delivering with high levels of precision. As suppliers develop competencies and capabilities they move up this ladder.

Expatriates as well as senior local managers are an important resource when expanding and spreading an organisational culture within a new territory. Tarnovskaya and de Chernatony (2011) argue that these individuals are important in ensuring things are done the IKEA way, both for large issues such as the IKEA concept but also smaller aspects such as the dress code. This group, often referred to as 'IKEANs', play a key role in policing the IKEA concept. Whilst experienced IKEAN's are used to impart corporate and internationalisation knowledge (Jonsson and Foss, 2011), there is a clear strategy within new markets of recruiting open-minded individuals (Young Potentials) to the workforce:

"I think we have - as many global companies - a paradox built into how we do business around the world. With one mouth we say that you have to know and breath the IKEA way of doing business, the IKEA culture, etc. To have this you have to have been in the IKEA world for a while, it is something you learn through everyday business, it is not something you can learn from a book. But, given that, we also have 
to acknowledge that knowledge of the local conditions are very important to plant our concept in different markets. And who are better at doing that than people from the local markets. So while we can use the expats for set-ups and changes and projects, the basis in the different markets have to be local people who have a knowledge about local conditions and the local market that there is no way of Älmhult having" (interview respondent)

Over time, IKEA has developed systematised ways of making sure that local market embeddedness of the IKEA concept is achieved. Before the return to Japan in 2006, IKEA sought to connect more deeply with the Japanese market than on the initial market entry in 1997. This involved networking mechanisms and an unprecedented level of consumer market engagement. First, several thousand consumer visits and interviews were conducted to understand the Japanese customer. Second, the Young Potential Program recruited Scandinavians (mainly Swedes) who spoke Japanese and/or had an in-depth knowledge of Japanese culture. Eventually around 50 staff were recruited and sent to stores and offices around the world for an IKEA 'education', before moving to Japan to open the first store. Unusually, the first country manager for IKEA Japan was not an established IKEA manager, but an outsider who understood Japan (rather than IKEA). This approach had never been seen before in IKEA, clearly an adaption specific to the Japanese market to enable a deep territorial embeddedness.

\section{Discussion and Conclusion}

In the analyses of international retailing there has been considerable debate on the dialectics of 'local versus global' in terms of strategy. This has mirrored a much more extensive debate in the international business literature. Within retailing it has become clear that the global $\mathrm{v}$. local discussion is at a much too coarse a level of abstraction. This paper has attempted to deconstruct the nature of the operation of an international retailer by considering the nature of the embeddedness of the retailer in a new market, linking this to the various components of the business model.

As an international retailer becomes integrated into new commercial and consumer environments it makes decisions on the adaption of its business model in response to the new environment. Owing to the nature of retailing, adaptations are most visible in the consumer facing elementsloutputs of the business model and a focus on these aspects has framed much of the past debate. Developing the conceptualisation of Hess, three categories of retailer 
embeddedness are present, namely societal, network, and territorial. For retailers these three categories each have a dominant process by which embeddedness is executed: processes of transfer in societal embeddedness, negotiation in network embeddedness and adaption in territorial embeddedness. The processes are not exclusive to a category but characterise the activities in the respective categories. These forms of embeddedness and processes can be linked to the different aspects of the internationalising firm's business model. A synthesis is possible between the forms of embeddedness and the components of the businesses model, using an amended Osterwalder and Pigneur business model framework, which provides a deeper understanding of the adjustments made by a retailer as it becomes competitive in a new market. Figure 6 provides a summary example of the links between the components in the business model framework and the categories of embeddedness identified by Hess.

Applying this synthesis to the study of IKEA shows a particularly strongly rooted societally embedded business model that nonetheless is adjusted as IKEA becomes embedded in new markets. With respect to societal embeddedness, there is a clear transfer of the core value proposition and the activities and behaviours associated with customer facing and resource and infrastructure activities. These combined elements of the IKEA business model provide a distinctive proposition and branded retail formulae. Edvardsson and Enqvist (2002) recognise in their study of IKEA that "a strong service culture, based on the logic of values that make sense inside the company as well as outside, is a strong driving force.” (p182)

In IKEA the creation of network embeddedness occurs through negotiated relationships with many stakeholders. There are relationships with the suppliers of products who are required to fabricate the designs supplied by IKEA but the negotiated relationships with suppliers provide for mutual exchange of knowledge, although IKEA remains the dominant power in negotiations. Relationships with the network of consumers generate network embeddedness with consumers gaining an understanding of the values of IKEA and how to shop the stores and become part of IKEA 'family'. Knowledge is gained by consumers and by IKEA across several components of the business model as the consumer-retailer network is negotiated. The creation of a chain of stores in a market enables network embeddedness and involves negotiation with a variety of agencies, often different not only in different countries but also in the various locations in a market.

IKEA's strong value proposition means that the scope for radical adaption to create territorial embeddedness is constrained. Other firms in other sectors, particularly if the item sold is 
Figure 6: Relationships between business model components and categories of embeddedness

\begin{tabular}{|c|c|c|c|}
\hline \multirow{2}{*}{ Business Model Components } & \multicolumn{3}{|c|}{ Categories of Embeddedness } \\
\hline & Societal & Network & Territorial \\
\hline Value Proposition & Transfer core brand values & $\begin{array}{l}\text { Develop scale and scope economies } \\
\text { through networks of formulae }\end{array}$ & $\begin{array}{l}\text { Adapt format and formulae to local } \\
\text { consumers } \\
\text { Adapt brand to local societal nuances }\end{array}$ \\
\hline Key Partners & $\begin{array}{l}\text { Transfer corporate culture to acquired } \\
\text { firms }\end{array}$ & $\begin{array}{l}\text { Negotiate relationships with new supply } \\
\text { chain partners and institutions in the } \\
\text { socio-political environment. } \\
\text { Leverage supply chain networks of } \\
\text { existing supplier } \\
\text { Integrate acquisitions }\end{array}$ & Adapt relationships to local partners \\
\hline Key Activities & $\begin{array}{l}\text { Transfer corporate vision } \\
\text { Transfer governance strategy } \\
\text { Transfer knowledge to partners }\end{array}$ & Negotiate with governance partners & $\begin{array}{l}\text { Adapt vision to macro socio-political } \\
\text { factors } \\
\text { Seek to change to market to support the } \\
\text { corporate vision } \\
\text { Adapt to local legal requirements of } \\
\text { governance }\end{array}$ \\
\hline Key Resources & $\begin{array}{l}\text { Transfer systems and knowhow } \\
\text { Transfer finance for investment from } \\
\text { home to start-up markets }\end{array}$ & $\begin{array}{l}\text { Build network of points of transaction } \\
\text { Develop a network of knowledge flows } \\
\text { Build internal network of international } \\
\text { management }\end{array}$ & $\begin{array}{l}\text { Adapting management development and } \\
\text { training programmes for local employees. }\end{array}$ \\
\hline Customer Relationships & $\begin{array}{l}\text { Transfer the service ethos of the focal } \\
\text { firm } \\
\text { Transfer infrastructure of loyalty } \\
\text { programme }\end{array}$ & $\begin{array}{l}\text { Export of retail brand items to other } \\
\text { retailers }\end{array}$ & $\begin{array}{l}\text { Adapt employee-customer interaction } \\
\text { policies } \\
\text { Adapt loyalty programme to local } \\
\text { customers }\end{array}$ \\
\hline Channels & Transfer format(s) to market & $\begin{array}{l}\text { Develop network of points of transaction } \\
\text { Co-ordinate multi-channel network to } \\
\text { generate channel synergies }\end{array}$ & Adapt channel mix to local market \\
\hline Customer Segments & Target same customer group and values & & $\begin{array}{l}\text { Adapt target segments } \\
\text { Adapt to local demographics of target }\end{array}$ \\
\hline
\end{tabular}


worn or eaten, are likely to undertake more adaption to become territorially embedded. Nonetheless IKEA still adjusts its sales formula, consumer communication methods and messages in order to resonate with local territorial socio-cultural traditions. The Jonsson and Foss (2011) distinction between the 'idea concept' and 'concept in practice' is a relevant framework here. They identify three phases of retail internationalisation: exploration, when the concept was evolving; exploitation, when a format and modus operandi was imposed on markets; and the current approach termed flexible replication, where the 'idea concept' (the core values, cultural identity etc.) is fixed but the 'concept in practice' allows variations in the implementation of identity at the local level i.e. in the territory of operation. The adaption processes become more significant as knowledge about the nuances of the market are obtained and integrated into the components of the business model.

Actions within the components of the business model impinge to a different extent on the various forms of embeddedness. Some actions affect one form of embeddedness almost exclusively. Others impinge of several forms, for example the catalogue in the IKEA business model enhances societal embeddedness through communication of IKEA values, network embeddedness through its communication with the consumer network, and territorial embeddedness with the minor, but still relevant, differences in language and distribution.

In applying the synthesis between frameworks of embeddedness and business model we are aware that IKEA is a unique firm in many respects. It is unique in the strength of its corporate vision, the relatively small number of stores for its scale of operations, the nature of relationships in its demand chain network and its governance structure. It has a unique business model. IKEA has been widely studied and it has generally been asserted that it makes few adaptions when it moves into new markets. A conclusion of our study questions this and shows that if we consider the different types of embeddedness related to the components of the business model then there is substantial adaption or adjustment in some aspects of IKEA's operations.

There are a number of areas where the current research approach could be developed. The different sectors of retailing have fundamentally different business models and have very different levels of investment in the three categories of embeddedness. Furthermore within these sectors individual firms have their own detailed business models. Not only is IKEA a unique firm but it operates in a retail sector (furniture and furnishings) with specific characteristics. Tokatli (2014) makes a strong argument for the power of substantive case 
studies as a research design to elicit new insights and our study of IKEA supports her argument. We suggest that the approach of this paper be developed for other firms in other retail sectors. It has been suggested that retailer internationalisation in a firm can be seen, at a general level, as developing through a series of processes of entry, development with subphases of stabilisation, consolidation, control and domination, with review and withdrawal activity being interposed at any stage (Dawson 2003). The interaction between business model and embeddedness is likely to be different in these various stages and these differences could be explored. This would enable a longitudinal study of the dynamics of the approach to be considered. A further potential area for development is in using the approach to explore the different types of knowledge flows that occur within the business model and with the various forms of embeddedness. In these areas of potential study a deep case study approach would be necessary and this would be advantageous in illustrating how the approach can be used with firms with very different governance structures and in sectors other than home furnishing.

\section{References}

Achabal, D., Heineke, J., McIntyre, S. H. (1985) Productivity measurement and the output of retailing. Journal of Retailing, 6(3): 83-88.

Alexander, N., Doherty, A. M. (2010) International retail research: focus, methodology and conceptual development. International Journal of Retail and Distribution Management, 38 (11/12): $928-942$.

Afuah, A. (2004) Business Models: A Strategic Management Approach. New York: Irwin/McGraw-Hill.

Amit, R., Zott, C (2002) Value drivers of e-commerce business models. In M. A. Hitt, R. Amit, C. Lucise, R. D. Nixon (eds) Creating Value: Winners in the New Business Environment, pp. 15-47. Oxford, UK: Blackwell.

Baden-Fuller., C. Morgan, M. S. (2010) Business models as models. Long Range Planning, 43: 156-171.

Baraldi, E. (2008), Strategy in industrial networks: Experiences from IKEA. California Management Review, 50(4): 99-126.

Bartlett, C. A., Nanda, A. (1988), Ingvar Kamprad and IKEA. In R.D. Buzzell, J.A Quelch, C. Bartlett, Global Marketing Management : Cases and Readings, pp. 72-99, $2^{\text {nd }}$ edition, Reading, Massachusetts: Addison Wesley. 
Bartlett, C. A., Nanda, A. (1990), Ingvar Kamprad and IKEA, Harvard Business School Case 390-132 (revised 1996).

Bartlett, C. A., Dessain, V., Sjöman, A. (2006) IKEA'S global sourcing challenge: Indian rugs and child labour. Harvard Business School Case 906-41

Barthélémy, J. (2008) IKEA: les fondements d'une strategie revolutionaire, Paris: ESSEC Publishing

Beamish, P. (1988) IKEA (Canada) ltd 1986. (Consolidated). London, Ontario: Ivey Publishing, University of Western Ontario

Betancourt, R. (2004) The Economics of Retailing and Distribution. Cheltenham: Edward Elgar.

Bock, A. J., Opsahl, T., George, G., Gann, D. M. (2012) The effects of culture and structure on strategic flexibility during business model innovation. Journal of Management Studies, 49(2): 279- 305 .

Bucklin, L. P. (1972) Competition and Evolution in the Distributive Trades. Englewood Cliffs: Prentice Hall.

Burt, S. (1991) Trends in the internationalization of grocery retailing: the european experience. International Review of Retail, Distribution and Consumer Research, 1: 487-515.

Burt, S., Davies, K. (2010) From retail brand to retail-er brand: themes and issues in retail branding research, International Journal of Retail and Distribution Management, 38: 865-878.

Burt, S., Mavrommatis, A. (2006) The international transfer of store brand image, International Review of Retail, Distribution and Consumer Research, 16: 395-413.

Burt, S., Johansson, U., Thelander, Å. (2011a) (eds) Consuming Ikea. Different Perspectives on Consumer Images of a Global Retailer. Lund: Lund University Press.

Burt, S., Johansson, U., Thelander, Å. (2011b) International retail image - a comparative study in three countries. Journal of Retailing and Consumer Services. 18(3): 183-193.

Burt, S., Davies, K., Dawson, J., Sparks, L. (2008) Categorizing patterns and processes in retail grocery internationalization. Journal of Retailing and Consumer Services, 15: 7892.

Casadesus-Masanell, R., Ricart, J. E. (2010) From strategy to business models and onto tactics. Long Range Planning, 43: 195-215.

Cassinger, C. (2010) Retailing retold: unfolding the process of image construction in everyday practice. Lund Studies in Economics and Management, 115, Lund University Press 
Chesbrough, H. W. (2007) Business model innovation: it is not just about technology anymore. Strategy and Leadership, 35: 12-17.

Chesbrough, H. W. (2009) Business model innovation: opportunities and barriers. Long Range Planning, 43: 354-363.

Chinomona, R., Sibanda, D. (2012) When global expansion meets local realities in retailing: Carrefour's glocal strategies in Taiwan. International Journal of Business and Management, 8(1): 44-59.

Coe, N. M., Lee, Y-S. (2006) The strategic localization of transnational retailers: The case of Samsung-Tesco in South Korea. Economic Geography, 82(1): 61-88.

Coe, N. M., Lee, Y-S. (2013) 'We've learnt how to be local': the deepening territorial embeddedness of Samsung-Tesco in South Korea. Journal of Economic Geography, 13(2): 327-356.

Czintoka, M.R., Ronkainen, I.A. (1990) 'IKEA in the USA'. In M. R. Czintoka, I. A. Ronkainen, International Marketing, $2^{\text {nd }}$ edition, pp 203-207 London: Dryden Press.

Dacin, M.T., Ventresca, M., Beal, B. (1999) The embeddedness of organizations: dialogue and directions. Journal of Management, 23: 317-356.

Dahlvig, A. (2012) The IKEA Edge: Building Global Growth and Social Good at the World's most Iconic Home Store. Stockholm: Studentlitteratur AB, Sweden, McGraw-Hill

Dawson, J. A. (1994) Internationalization of retailing operations. Journal of Marketing Management, 10: 267-282.

Dawson, J. A. (2001) Strategy and opportunism in european retail internationalization. British Journal of Management, 12: 253-266.

Dawson, J. A. (2003) Introduction. In J. A. Dawson, M. Mukoyama, S. C. Choi, R. Larke, (eds) The Internationalisation of Retailing in Asia, pp. 1-5. London: Routledge Curzon

Dawson, J. A. (2005) Output considerations in retail productivity. International Review of Retail, Distribution and Consumer Research, 15(3): 337-349.

Dawson, J. A. (2007) Scoping and conceptualising retailer internationalisation. Journal of Economic Geography, 7: 373-397.

Dawson, J. A., Mukoyama, M. (2014) Building international strategy with formats and formulae. In J. A. Dawson, M. Mukoyama (eds). Global Strategies in Retailing: Asian and European Experiences, pp 37-54. London: Routledge.

Deligonul, S. Z., Elg, U., Cavusgil, E., Ghauri, P. N. (2013) Developing strategic supplier networks: an institutional perspective. Journal of Business Research, 66(4): 506-515.

Dicken, P. (2000) Places and flows: situating international investment. In Clark, G. L., Feldman, M. P. and Gertler, M. S. (eds.): The Oxford Handbook of Economic Geography. pp. 275-291. Oxford: Oxford University Press. 
Dicken, P. (2003): "Placing" firms: grounding the debate on the "global" corporation. In: J. A. Peck and H. W-C.Yeung (eds.). Remaking the Global Economy: EconomicGeographical Perspectives. pp. 27-44. London: Sage.

Douglas, E. (1975) The Economics of Marketing. New York: Harper \& Row.

Dunford, R, Palmer, I., Benveniste, J (2010) Business model replication for early and rapid internationalisation: the ING direct experience. Long Range Planning, 43: 655-674.

Dupuis, M., Fournioux, J. (2006) Building an international retail strategy. In J. Dawson, R. Larke, M. Mukoyama (eds) Strategic Issues in International Retailing, pp51-70. Abingdon: Routledge.

Edvardsson, B., Enquist, E. (2002) 'The IKEA saga': how service culture drives service strategy. Service Industries Journal, 22(4): 153-186

Edvardsson, B. Enquist, E. (2009) Values-based Service for Sustainable Business: Lessons from IKEA. Abingdon: Routledge.

Edvardsson, B, Enquist, E., Hay, M. (2006) Values-based service brands: narratives from IKEA. Managing Service Quality, 16(3): 230-246.

Elg, U., Deligonul, S. Z., Gauri, P. N., Danis, W., Tarnovskaya, V. (2011) Market-driving strategy implementation through global supplier relationships. Industrial Marketing Management, 66: 506-515.

Fletcher, R. Barrett, N. (2001) Embeddedness and the evolution of global networks: an Australian case study. Industrial Marketing Management, 30(7): 561-573.

Ford, D., Gadde, L. E., Håkansson, H., Lundgren, A., Snehota, I., Turnbull, P., Wilson, D. (1998) Managing Business Relationships. London: Wiley

Gamble, J. (2010) Transferring Organizational Practices and the Dynamics of Hybridization: Japanese Retail Multinationals in China. Journal of Management Studies, 47(4): 705732

George, A. L., Bennett, A. (2005) Case Studies and Theory Development in the Social Sciences. London: MIT Press.

Ghauri, P. N., Tarnovskaya, V., Elg, U. (2008) Market driving multinationals and their global sourcing network. International Marketing Review, 25(5): 504 - 519.

Giesen, E., Berman, S. J., Bell, R., Blitz, A. (2007) Three ways to successfully innovate your business model. Strategy and Leadership, 35: 27-33.

Gielens, K., Dekimpe, M. G. (2001) Do international entry decisions for retail chains matter in the long run? International Journal of Research in Marketing, 19: 235-259. 
Goldman, A. (1981) Transfer of retailing technology into lesser developed countries: The supermarket case. Journal of Retailing, 57(2): 5-29.

Granovetter, M. (1985) Economic action and economic structure: the problem of embeddedness. American Journal of Sociology, 91: 481-510.

Granovetter, M. (1992) Problems and explanation in economic sociology. In N. Nohria and R. G. Eccles (eds) pp.25-56. Boston, MA: Harvard Business School Press.

Halinen, A., Törnroos, J-Å. (1998) The role of embeddedness in the evolution of business networks. Scandinavian Journal of Management, 14(3): 187-205.

Hedman, J., Kalling, T. (2003) The business model concept: theretical underpinings and empirical illustrations. European Journal of Information Systems, 12: 49-59.

Heidenreich, M. (2012a) editor. Innovation and Institutional Embeddedness of Multinational Companies. Cheltenham: Edward Elgar.

Heidenreich, M. (2012b) The social embeddedness of multinational companies: a literature review. Socio-Economic Review, 10: 549-579.

Helfferich, E., Hinfelaar, M., Kasper, H. (1997) Towards a clear terminology on international retailing. International Review of Retail, Distribution and Consumer Research, 7(3): 288-307.

Hess, M. (2004) 'Spatial' relationships? Towards a reconceptualization of embeddedness. Progress in Human Geography, 28: 165-186

Hollander, S. (1970) Multinational Retailing. East Lansing: Michigan State University.

Hrelja, R., Isaksson, K., Richardson, T. (2012) IKEA and small city development in Sweden: planning myths, realities, and unsustainable mobilities. International Planning Studies, 17(2): 125-145.

Huy, Q., Jarrett, M., Duke, L. (2011) How IKEA's Strategy was Formed. Paris: INSEAD.

Håkansson, H., Ford, D. (2002) How should companies interact in business networks? Journal of Business Research, 55: 133-139.

Håkansson, H., Ford, D., Gadde, L.-E., Snehota, I., Waluszewski, A. (2009) Business in Networks. Chichester: Wiley.

IKEA (2003) The IKEA Way - Social and Environmental Responsibility. Älmhult: IKEA.

IKEA supply AG (2008) IWAY Standard. Leiden: INGKA Holding B.V.

IKEA corporate website 2009-01-08, http://www.ikea-group.ikea.com/ 
Ivarsson, I., Alvstam, C. G. (2010) Supplier upgrading in the home-furnishing value chain: an empirical study of IKEA's sourcing in China and South East Asia. World Development, 38(11): 1575-1587.

Ivarsson, I., Alvstam, C. G. (2011) Upgrading in global value-chains: a case study of technology-learning among IKEA-suppliers in China and Southeast Asia. Journal of Economic Geography, 11(4): 731-752.

Johnson, M. W., Christensen, C. C., Kagermann, H. (2008) Reinventing your business model. Harvard Business Review, 86(12): 50-59.

Johansson, U., Thelander, Å. (2009) A standardised approach to the world? IKEA in China. International Journal of Quality and Service Science, 1(2): 199-219.

Jonsson, A. (2007), Knowledge sharing across borders - a study in the IKEA world. Lund Studies in Economics and Management, 97. Lund University Press.

Jonsson, A. (2008) A transnational perspective on knowledge sharing: lessons learned from IKEA's entry into Russia, China and Japan. International Review of Retail, Distribution and Consumer Research, 18 (1): 17-44.

Jonsson, A., Elg, U. (2006) Knowledge and knowledge sharing in retail internationalisation: IKEA's entry into Russia. International Review of Retail, Distribution and Consumer Research, 16(2): 239-256.

Jonsson, A., Foss, N. J. (2011) International expansion through flexible replication: Learning from the internationalization experience of IKEA. Journal of International Business Studies, 42: 1079-1102.

Jonsson, A. Kalling, T. (2007) Challenges to knowledge sharing across national and intraorganisational boundaries: case studies of IKEA and SCA Packaging. Knowledge Management Research \& Practice, 5: 161-171.

Kamprad, I. (1976) Testament of a Furniture Dealer. Älmhult: IKEA.

Kumar, N., Steenkamp, J-B. E. M. (2007) Private Label Strategy: How to Meet the Store Brand Challenge. Boston: Harvard Business School Press

Laulajainen, R. (1991) Two retailers go global. International Review of Retail, Distribution and Consumer Research, 1(5): 607-636.

Lewis, E. (2005) Great IKEA! A Brand for All the People. St Peter Port: Cyan Books.

Lindqvist, U. (2009) The cultural archive of the IKEA store. Space and Culture, 12(1): 4392.

Lowe, M., Wrigley, N. (2010) The "continuously morphing" retail TNC during market entry: interpreting Tesco's expansion into the United States. Economic Geography, 86 (4): $381-408$

Magretta, J. (2002) Why business models matter. Harvard Business Review, 80 (5): 86-92. 
Mårtensson, R. (1981) Innovation in Multinational Retailing. Goteburg: University of Goteburg.

Mårtensson, R. (1987) Is standardisation of marketing feasible in culture-bound industries?: a european case study. International Marketing Review, 4(3): 7-17.

Matusitz, J., Forrester, M. (2009) Successful glocalization practices: the case of Seiyu Japan. Journal of Transnational Management, 14: 155-176.

Matusitz, J., Leanza, K. (2009) Wal-Mart: an analysis of the glocalization of the cathedral of consumption in China. Globalizations, 6(2): 187-205.

Matusitz, J., Reyers, A. (2010) A behemoth in India Walmart and glocalisation. South Asia Research, 30(3): 233-252.

McClelland, G. (1966) Costs and Competition in Retailing. London: Macmillan.

Moon, Y. (2004) IKEA invades America. Harvard Business School Case 504-094.

Moran, P. ( 2005) Structural vs. relational embeddedness: social capital and managerial performance. Strategic Management Journal, 26: 1129-1151.

Moore, C., Fernie, J., Burt, S. (2000) Brands without boundaries: the Internationalisation of the designer retailers' brand. European Journal of Marketing, 34(8): 919-937.

Oinas, P. (1998) The embedded firm. Prelude for a revised geography of enterprise. Doctoral thesis A-143 Helsinki School of Economics and Business Administration

Osterwalder, A., Pigneur, Y., Tucci, C. L. (2005) Clarifying business models: origins, present and future of the concept. Communications of the Association for Information Systems, 16: $1-25$.

Osterwalder, A., Pigneur, Y. (2010) Business Model Generation: A Handbook for Visionaries, Game Changers, and Challengers. Hoboken: John Wiley \& Sons.

Pütz, M. (2011) Power, scale and IKEA: analysing urban sprawl and land use planning in the metropolitan region of Munich, Germany. Procedia - Social and Behavioral Sciences, 14: $177-185$.

Richardson, J. (2008) The business model: An integrative framework for strategy execution. Strategic Change, 17(5/6): 133-144.

Rugman, A., Girod, S. (2003) Retail multinationals and globalization: the evidence is regional. European Management Journal, 21(1): 24-37.

Salzer, M. (1994) Identity across borders: a study in the IKEA world. Studies in Management and Economics, 27 Linkoping: Linkoping University,

Sorescu, A., Framback, R. T., Singh, J., Rangaswamy, R., Bridges, C. (2011) Innovations in retail business models. Journal of Retailing, 87(1): 83-96. 
Stenbo, J. (2010) The Truth about IKEA: The Secret Behind the World's Richest Man and the Success of the Flatpack Giant. London: Gibson Square.

Tacconelli, W., Wrigley, N. (2009) Organizational challenges and strategic responses of retail TNCs in post-WTO-entry China. Economic Geography, 85, 49-73.

Tarnovskaya, V. (2007), The mechanisms of market driving with a corporate brand: the case of a global retailer, Lund Studies in Economics and Management 95, Lund University Press.

Tarnovskaya, V., Elg, U., Burt, S. (2008) The role of corporate branding in a market driving strategy. International Journal of Retail \& Distribution Management, 36(11): 941-965.

Tarnovskya, V., de Chernatony, L. (2011) Internalising a brand across cultures: the case of IKEA. International Journal of Retail \& Distribution Management. 39(8): 598-618.

Terpstra, V., Sarathy, R. (1990) IKEA. In V. Terpstra, R. Sarathy International Marketing, pp. 291-296. London: Dryden Press.

Tokatli, N. (2014) Single-firm case studies in economic geography: some methodological reflections on the case of Zara. Journal of Economic Geography doi: 10.1093/jeg/lbu013 First published online: May 29, 2014

Torekull, B. (1998) Historien om IKEA, Wahlstrom and Widstrand (reprinted in English as (1999) Leading by Design: The IKEA Story, New York: HarperBusiness).

Torekull, B. (2006) Historien om IKEA: Ingvar Kamprad berättar för Bertil Torekull. Stockholm: Wahlström \& Widstrand.

Treadgold, A. (1990) The developing internationalisation of retailing. International Journal of Retail and Distribution Management, 18(2): 4-11.

Tzeng, R., Uzzi, B. (2000) editors. Embeddedness and Corporate Change in a Global Economy. New York: Peter Lang.

Wei, L-Q., Zou, X (2007) IKEA in China: facing dilemmas in an emerging economy. Asian Case Research Journal, 11(1): 1-21.

Wood, S., Coe, N. M., Wrigley, N. (2014): Multi-Scalar localization and capability transference: Exploring embeddedness in the Asian retail expansion of Tesco, Regional Studies, DOI: 10.1080/00343404.2014.926317

Wrigley, N., Coe, N. M., Currah, A. (2005) Globalizing retail: conceptulizing the distribution-based TNC. Progress in Human Geography, 29: 437-457.

Yin, R. K. (2009) Case Study Research: Design and Methods. (4 ${ }^{\text {th }}$ edition) London: Sage.

Zander, U, Zander, L, Gaffney, S., Olsson, J (2010) Intersectionality as a new perspective in international business research. Scandinavian Journal of Management, 26: 457-466. 
Zott, C., Amit, R. (2010) Business model design: an activity system perspective. Long Range Planning, 43: 216-226.

Zott, C., Amit, R., Massa, L. (2011) The business model: recent developments and future research. Journal of Management, 37: 1019-1042.

Zukin, S., Di Maggio, P. (1990) Introduction. In: Structures of Capital: The social Organization of the Economy, pp. 1-36. Cambridge: Cambridge University Press. 